УДК: $101.1+372.83$

\title{
ОЛьга ГОНЧАРЕНКО
}

\section{ФІЛОСОФІЯ ТА ФІЛОСОФСЬКА ОСВІТА У РОЗУМІННІ КАЗИМИРА ТВАРДОВСЬКОГО}

\section{(до 150-річчя 3 дня народження філософа та педагога)}

Самовизначення філософії, ї̈ місце і призначення в жситті людини та суспільства - давня філософська проблема. Спробу ї̈ вирішення видатним

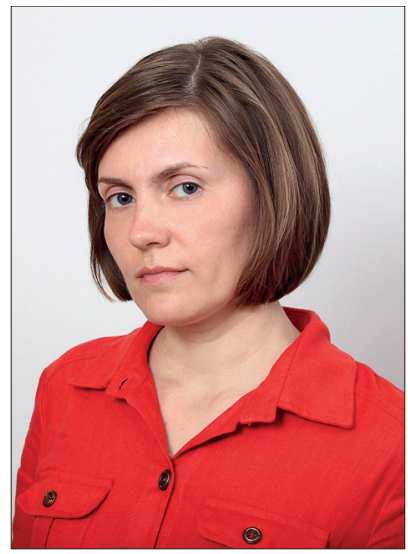
польським філософом, Казимиром Твардовським, запропоновано проаналізувати читачеві у статті. Вільна від крайнощів метафізицизму та мінімалізму філософія Твардовського не лише створила умови для розквіту філософської культури, але й виховала плеяду філософськи вишколених працівників. Вияв особливостей розуміння талановитим науковцем та педагогом філософії й передумови ї̈ розвитку - філософської освіти - спонукають до розмислів над проблемами у царині вітчизняної філософії. Філософсько-педагогічне осмислення досвіду Твардовського є актуальним і в контексті зростаючої складності сучасних взаємин людини і суспільства.

Ключові слова: польська філософія, Казимир Твардовський, філософія, філософська освіта.

Можливо, більше, ніж будь-коли людство безпомічно стоїть на схилі віку і не знає, куди повернутися. Отож, обов'язково потрібно, щоби хоча б філософи «голови не втрачали» та знали куди потрібно іти.

Казимир Твардовський Франи Брентано та історія філософії

Зважаючи на конструктивний підхід до історії філософії свого вчителя ${ }^{1}$, австрійського філософа Франца Брентано, засновнику ЛьвівськоВаршавської школи, польському філософу Казимиру Твардовському, вдалось створити таку філософію, яка виховала плеяду вчених, здатних сприяти не лише розвитку науки, але й творенню культури. 3 огляду

\footnotetext{
${ }^{1}$ Виклад Брентано історії філософії конструктивним методом полягає у виявленні загального закону, згідно з яким філософія розвивалася у своєму історичному поступі.
} 
проблеми самовизначення філософії, іiі місця і призначення в культурі концепції філософії та філософської освіти Казимира Твардовського не втрачають актуальності, особливо в Україні, де рецепція творчості філософа представлена малою кількістю напрацювань ${ }^{1}$ порівняно із Польщею2 ${ }^{2}$ Отож, спробуємо виявити розуміння філософії у працях Твардовського, а також необхідну передумову іiі розвитку на його погляд.

\section{Концепція філософії Казимира Твардовського}

Спосіб мислення Європи другої половини XIX століття значною мірою визначали позитивізм, емпіризм та еволюціонізм. Разом ці три напрями витворювали мінімалістську філософію, підставами якої були антиметафізицизм та сцієнтизм. Мінімалістська підстава характеризувалася тим, що надавала досвідові наукової цінності, вважала психологію основою філософії, вимагала перевизначення філософії. У такій сцієнтичній атмосфері проходило студіювання філософії Твардовського у Віденському університеті під керівництвом Брентано.

Австрійський філософ подібно до позитивістів та сцієнтистів виходив із досвіду та був противником метафізичних спекуляцій, проте відрізнявся від них тим, що прагнув уникнути мінімалістських обмежень філософії, обираючи внутрішній досвід вихідним пунктом досягнення об’єктивних результатів. Не піддаючи сумніву ясності та достовірності знань, заснованих на внутрішньому досвіді, Брентано ствердив безпосередню очевидність пізнання його психічних феноменів, які в свою чергу він визначив об’єктом дослідження психології. Відмінною ознакою усіх психічних феноменів філософ вважав інтенціональне внутрішнє існування, властивою ознакою - дійсне існування, а істотною ознакою -

\footnotetext{
${ }^{1}$ Верніков М. (1967) Львівсько-варшавська філософська школа і розвиток в ній матеріалістичних тенденцій : дис. ... канд. філос. наук : 09.00.01. - Л., 1967. - 435 с.; Домбровський Б. (2013) Школа одного схоларха // Vох-Голос, 2013. - № 14. С. 1-13; Іваник С. (2015) Що таке польська філософія й що вона може дати українській філософії? // SENTENTIAE, 2015. - XXXII (№ 1). - C. 128-142 та ін.

${ }^{2}$ Воленьский Я. (2004) Львовско-Варшавская философская школа / пер. с польск. В. Порус. - М.: «Российская политическая энциклопедия» (РОССПЭН), $2004-472$ c.; Ivanyk S. (2014) Filozofowie ukraińscy w Szkole Lwowsko-Warszawskiej. - Warszawa: Wydawnictwo Naukowe Semper, 2014. - 223 s.; Jadczak R. (1991) Kazimierz Twardowski : twórca szkoły lwowsko-warszawskiej. -Toruń: Adam Marszałek, 1991. - 142 s.; Jadczak R. (1997) Mistrz i jego uczniowie. - Warszawa : Scholar, 1997. - 226 s.; Kleszcz R. (2013) Metoda i wartości. Metafilozofia Kazimierza Twardowskiego. - Warszawa: Wydawnictwo Naukowe Semper, 2013. - 254 s.; Rechlewicz W. (2015) Nauka wobec metafizyki. Poglądy filozoficzne Kazimierza Twardowskiego. - Kielce, 2015. - 614 s.; Wojtysiak J. (2005) Edukacja filozoficzna w ujęciu Szkoły Lwowsko-Warszawskiej // Edukacja Filozoficzna. 2005. - nr 40. - s. 189-200; та ін.
} 
єдність сприймання. Така емпірична настанова у психології гарантувала, на його думку, науковість філософії.

Поділяючи переконання свого вчителя, Твардовський вже у Вступній лекції, прочитаній 1895 року у Львівському університеті, виступив проти розуміння філософії як апріорної науки. Вчений доводив, що філософія повинна розглядатись як наукове знання, що має віднайти своє місце серед спеціальних наук. У зв’язку з цим філософ заперечував відмінності між предметами досліджень філософських і природничих наук. До предмета природничих наук, на його думку, належить все, що діє на наші відчуття, тоді як, такі філософські науки, як психологія, логіка, етика і естетика займаються розумовими, духовними явищами. Але такий критерій вчений не зміг застосувати до метафізики, тому що вона, «будучи галуззю філософії, займається предметами, що знаходяться у близькому зв'язку як з предметами наук природничих, так і з предметами решти філософських наук» (Twardowski, 2013b: s. 460). Втім, така особливість предмета метафізики не заперечила у Твардовського можливості їі розгляду як науки. Символічно співвідношення метафізики, філософських та природничих наук філософ зобразив так:

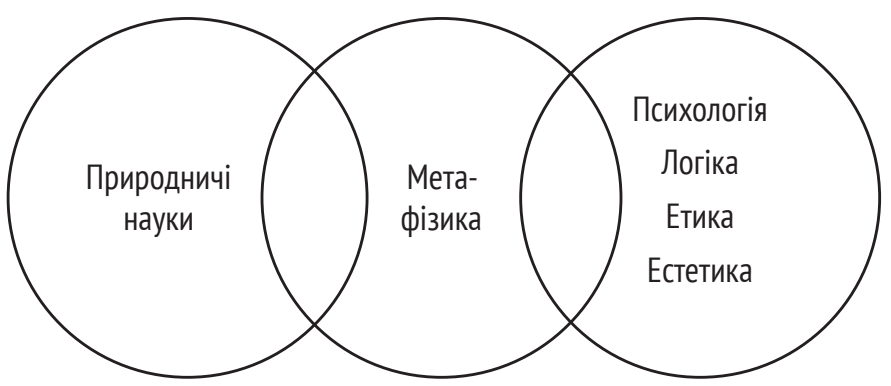

Прагнення вченого до унауковлення філософії зумовлювали його відмову від думки про те, що у філософії пізнання загального не можливе через окреме, одиничне, що загальне не можна пізнати на основі досвіду, а воно повинно бути вищим за досвід «й черпатись з джерела понять, які дрімають на дні людської душі» (Twardowski, 2013b: s. 463). На його переконання така методологічна позиція спричинила у філософіï «множинність систем, які борються між собою, а вічний спір філософів і майже повна відсутність згоди, породили недовіру у загалу, а згодом зневагу й ігнорування» (Ibid.). Тотожність предметів дослідження філософських і природничих наук однозначно вирішувала для Твардовського питання їхнього методу: філософські науки можуть позбутись апріорності й довільності лише за умови використання методу, аналогічного до методу природничих наук. Тому Твардовський рішуче відмовлявся від 
філософії як чисто спекулятивної науки, а пропонував зосередитись на збиранні відомостей, які у майбутньому могли б згодитись для творення єдиної істинної системи філософії. Таку ж методологічну позицію Твардовський обгрунтовував щодо метафізики. Доведення Твардовським відсутності відмінностей між філософськими та природничими науками утвердило мету філософії не у рубрикуванні їі по різноманітним -ізмам, системам, напрямам та школам, а у пошуку істини та іiі науковому обгрунтуванні.

У праці Психологія стосовно фізіології та філософії (1897) Твардовський продовжував розвивати розуміння наукової філософії, а також репрезентував у ній, як і його вчитель, психологістичну точку зору. Вчений припускав, що психічна діяльність є напевно функцією мозку, оскільки певні зміни, що відбуваються в мозку, тягнуть за собою зміни в психічній діяльності, попри це він не міг назвати психічну дію функцією мозку, оскільки зовсім не мав доказів того, що психічну діяльність повністю й винятково здійснює мозок. Через це він не погоджувався з тими вченими, які хотіли зробити з психології частину фізіології. Різниця між фізіологією та психологією з методологічної точки зору полягала, за Твардовським, передусім у тому, що психологія не може користуватися у своїх дослідженнях обсервацією, тоді як фізіолог постійно обсервує явища, якими займається у своїх дослідженнях. Натомість психолог може дані йому у внутрішньому досвіді явища психічного життя тільки помічати й спостерігати: «кожен психолог деякою мірою вдивляється в себе, у свій розум, а те, що в ньому спостерігає через внутрішній досвід, намагається аналізувати, описати, класифікувати, затвердити в правах» (Twardowski, 1927f: s. 9). Обсервацію психічних явищ унеможливлює ще й інша обставина: «мисляча людина не може розділитися на дві істоти, з яких одна би думала, а друга спостерігала б за мисленням (Ibid.). Отже, «внутрішній досвід не є фантазією затурканих психологів; навпаки, він становить єдиний спосіб, яким можемо почерпнути безпосереднє знання щодо психічних явищ» (Twardowski, 1927f: s. 13). Власне, на цій підставі Твардовський заперечив зарахування психології до фізіології.

Питання про відношення психології до філософії Твардовський вирішував на підставі визначення філософії. На його переконання, однією 3 найбільш характерних рис тогочасної філософської праці був «психологізм» філософії як проявлення в ньому певної реакції проти «метафізицизму» філософії як іiі тяжіння до апріорного вирішення досліджуваних проблем. Водночас аналіз досягнень філософії на підставі психології спонукав Твардовського до висновування того, що психології належить становище визначальної філософської науки. 3 огляду на таке особливе значення психології для сучасної філософії, Твардовський вважав вда- 
лим «тільки таке визначення філософії, яке дає змогу назвати філософською наукою не тільки метафізику, а й психологію» (Twardowski, 1927f: s. 26). Отже, розуміння філософії вчений уточнив наступним чином: «Поняття «філософія» означає групу наук, схоже як поняття «теологія» чи «природознавство» (Twardowski, 1927f: s. 27). Спільною рисою, на підставі якої Твардовський зачисляв окремі філософські науки до однієї групи наук, є певна властивість об’єктів, котрими вони займаються: «усі вони досліджують об’єкти, котрі нам даються або винятково у внутрішньому досвіді, або однаково у внутрішньому та у зовнішньому» (Ibid.). 3 такого визначення об’єкта філософських наук вчений виводив окремі напрями філософії: логіку, теорію пізнання, естетику, етику та метафізику.

Як бачимо, Твардовський розумів філософію як цілісність філософських наук й водночас як їх окремість. Таким розумінням філософії вчений не впадав у суперечність з особливим характером, якого він надавав філософським дослідженням психологією, ані також не наражався на закид, що відкидав із неї метафізику, котра як-не-як вважалася філософською.

Неодмінною умовою унауковлення філософії Твардовський визначив ясність філософського способу мислення. Аргументація Твардовським тісного зв'язку між мисленням і мовою спростовувала думку про те, що «неясність стилю прямо пропорційно залежить від глибини змісту філософських праць» (Twardowski, 1927d: s. 204) й доводила, що «той, хто ясно мислить, теж ясно б писав» (Ibid.). Ті ж, автори, які пишуть неясно, на думку філософа, не вміють ясно мислити, й, ймовірно, деякі з них навіть «не спроможні помітити неясності своїх думок. [...] а, отже, і неясності свого власного стилю» (Twardowski, 1927d: s. 205). Відстоювання філософом істинності доведеної думки піддавало сумніву необхідність обов’язку «ламати собі голову над тим, що саме автор-філософ має на увазі, пишучи неясним стилем» (Ibid.), оскільки він «не вміє ясно виражати свої думки, не вміє також ясно й мислити» (Ibid.), а значить «його думки не заслуговують на те, щоб ми намагалися їх розгадати» (Ibid.). Ясність мови філософії Твардовський пов’язав із чітким висловлюванням та необхідністю уникнення непорозумінь у справах наукової термінологіі.

Згодом Твардовський все ж переглянув можливості метафізики як науки. Вчений висловив припущення про те, «що між філософським, тобто метафізичним, поглядом на світ і наукою лежить нездоланна прірва» (Twardowski, 1929: s. 8). Такі надважливі для кожної людини метафізичні проблеми як сутність, початок, мета всякого буття, призначення людини тощо вчений визнав світоглядними проблемами, тобто такими, 
що не можна обгрунтувати науковими методами. Проте філософ не нехтував значимістю для людини філософського погляду на світ та життя. Світогляд, за Твардовським, є дороговказом в житті людини, кожна людина «має право прийняти той погляд на світ і життя, який йому «відповідає»» (Twardowski, 1929: s. 10), але «такий погляд є особистою справою для тих, які його поділяють» (Ibid.). Філософський, тобто метафізичний, погляд на світ $є$, на думку вченого, не науковим, але переднауковим, а отже, таким, яким наука не повинна легковажити, «адже в цих ненаукових поглядах на світ і життя може ховатися не одна істина, до котрої, щоб виявилося усе ії значення, потрібно тільки наукового підходу» (Twardowski, 1929: s. 13). Втім до можливості завершеного наукового погляду на світ Твардовський поставився скептично. Значення філософських наук у творенні наукової картини світу полягає, за визначенням вченого, у заспокоєнні істотної потреби людського розуму - потреби в шуканні істини. Унаслідок цього Твардовський вимагав від філософа залишити свої світоглядні переконання за межами методологічної дослідницької праці.

Слід також зазначити, що Твардовський вдавався до історичного поняття філософії. Вимогу включення до змісту поняття «філософія» рис науковості й ненауковості, теоретичності й практичності задовольнило таке поняття філософіï, у якому роль genus proximum відіграло поняття «витвору людського духу» (Twardowski, 1938: s. 7). Витвори людського духу філософ поділив на дві групи: «одна охоплює витвори, що є умовою виникнення, закріплення, взаємного повідомлення, сприйняття і передачі витворів другої групи, тобто релігії, науки, мистецтва, практичної діяльності і філософії» (Ibid.). Між філософією, з одного, та релігією, наукою, мистецтвом і практичною діяльністю, з іншого боку, Твардовський визначив ланки подвійного типу. Ланки першого типу виникають тоді, коли один витвір стає предметом або змістом другого витвору (коли говорять про філософію релігії, науки, мистецтва, діяльності або життя, i, навпаки, коли йдеться про філософський зміст релігійних вірувань, ... філософія стає змістом практичної діяльності в пропаганді і викладанні філософії). Прикладом ланки першого типу у розумінні Твардовським історичного поняття філософії можуть слугувати схеми 2,3.

До другого типу філософ відніс ланки, «які є чимось перехідним між двома різними витворами, чимось, що не є виключно ані одним, ані другим з цих витворів, але, однак, має в собі чинники, що належать до кожного з них - як наприклад теологія, ланка перехідна між релігією та наукою» (Twardowski, 1938: s. 8). (схема 4). Водночас Твардовський вказував, що не існує ланок другого типу між філософією та рештою витворами (схема 5). 


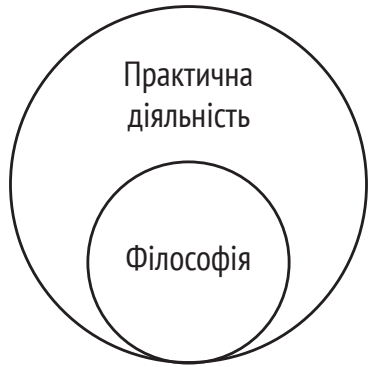

Cхема 2

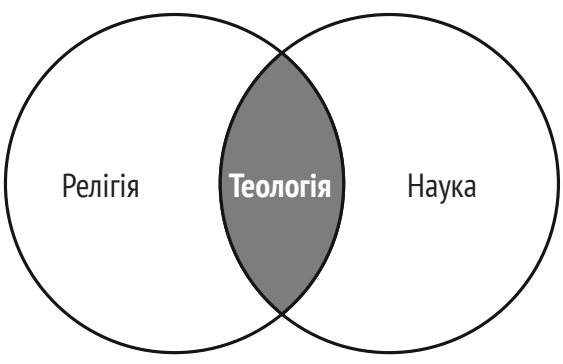

Схема 4

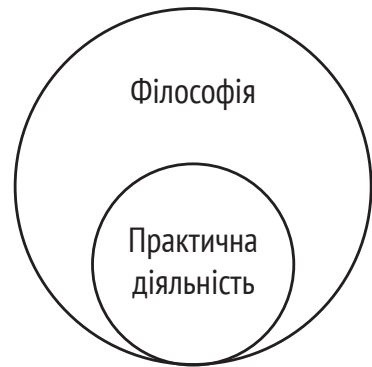

Схема 3

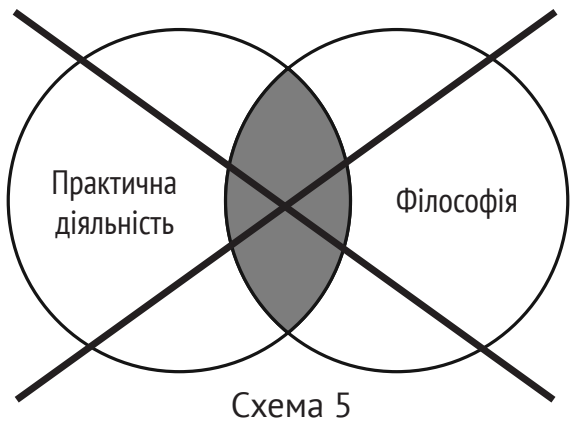

У цьому differentia specyfica поняття філософія, яка «сама стає перехідною ланкою між цими чотирма витворами і завдяки цьому займає серед них центральне місце, маючи у собі чинники кожного з них і сягаючи своїми гранями і відгалудженнями в кожний з них» (Twardowski, 1938: s. 8-9) (схема 6).

Безсумнівно, історичне поняття філософії Твардовського спрямоване на розгляд філософії у контексті духовної культури людини та суспільства. Філософія - духовний стрижень, що об'єднує багатоманіття виявів людського духу у певну цілісність. «Наукове» поняття філософії розчиняється у історичному понятті філософії, виступаючи одним із компонентів полілогу виявів людського духу, забезпечуючи цілісність суб'єкта пізнання.

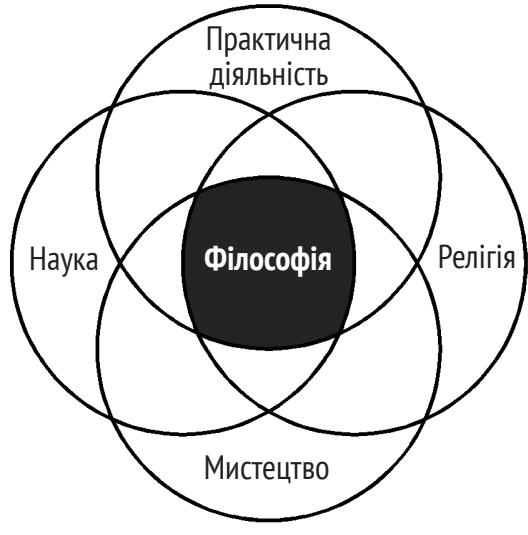

Схема 6 
До історичного поняття філософії вчений також звернувся у зв'язку із ситуацією, що складалася довколо філософії у тодішньому польському суспільстві. Вчений писав: «Суспільство замало вкладає у філософію, замало також видає із себе осіб, які присвячуються філософії. Першопричини цього стану речей приховані дуже глибоко. [...] Але одне, принаймні, не підлягає сумніву - те, що лише тоді освічена частина суспільства горнеться до філософії і виявляє розуміння ії потреб, коли сама відчуває потребу у філософії. Тому шлях до задоволення потреб філософії лежить через відчуття цих потреб. Філософія ж, будучи спільною надбудовою релігії, науки, мистецтва і практичної діяльності - стає потребою для освіченої частини суспільства тоді, коли воно, скуштувавши духовних скарбів, які може на даному етапі розвитку черпати з релігії, науки, мистецтва та практичної діяльності - не зупиняється на цьому, але прагне сягнути далі, а разом з тим - вище - до цілості, котра охоплює всі витвори людського духу - до філософського погляду на світ. Сила відчуття суспільством потреби у філософії залежить лише від міри загального духовного поступу, що в ньому відбувається. Це відчуття не можна збудити безпосередньо до цього спрямованими способами. Освічений загал повинен піднятись на відповідний рівень чуттєвої культури, а тоді сам відчує у собі потребу у філософії. Тоді ж і видасть із себе відповідну кількість працівників на ниві філософії і не пошкодує засобів, які полегшують їм плідну діяльність. Допоки це відчуття обмежується відносно нечисленними представниками філософії - мусять вони не лише займатись філософією, але також іiі пропагувати. Не маючи змоги розраховувати на загальне визнання потреби у філософії, мусять прищеплювати ії культ в невеликих товариствах і намагатись ці згромадження побільшувати» (Twardowski, 1927e: s. 162-163). 3 цієї цитати маємо ще одне підтвердження того, що Твардовський не недооцінював філософію як філософський погляд на світ та життя, оскільки цей погляд є цілістю, що охоплює всі витвори людського духу. Суттєво також, що філософія - це потреба людини та суспільства. Якщо людина та суспільство через брак своєї духовної культури не відчувають потреби у філософії, то цю потребу слід виплекати.

Отже, можна висновувати, що погляд польського вченого на філософію базувався на визнанні науки парадигмою побудови філософії. Філософія, за Твардовським, складається з п’яти основних філософських наук: теорії пізнання, психології, логіки, етики та естетики. В єдину цілість усі філософські науки об’єднує об’єкт їхнього дослідження - предмети, дані у внутрішньому досвіді. Через це психологію вчений вважав визначальною філософською наукою. Саме психологія досліджує прояви психічного життя, що даються лише через внутрішній досвід. Ясність 
філософського стилю науковець визначав умовою унауковлення філософії. 3 цією умовою він пов’язував вимогу термінологічної однозначності у філософії. Водночас саме ці особливості філософії становлять, на думку Твардовського, сутність духовної культури людини та суспільства. Власне тому чи не найголовнішою метою життя філософа була турбота про філософську освіту.

\section{Концепція філософської освіти Казимира Твардовського}

Про незадовільний стан справ довкола філософської освіти у гімназіях та університетах Твардовський писав у статті Навчання філософської пропедевтики у гімназіях (1902). Зазначимо, що під філософської пропедевтикою науковець розумів логіку та психологію, називаючи їх базовими науками у вивченні філософії. У цій статті філософ порушив питання про значимість філософської пропедевтики у «привчанні учнів до самостійного критичного мислення» (Twardowski, 1927c: s. 168). У зв'язку з цим він висловлювався за включення філософської пропедевтики до переліку предметів екзамену на атестат зрілості, вважаючи такий підхід найлегшим та найправдивішим способом оцінки дозрілості абітурієнтів. Вчений справедливо пов’язав брак кваліфікованих вчителів філософської пропедевтики у гімназіях із незаохоченням до навчання філософії академічної молоді. Особливого значення у навчанні філософської пропедевтики Твардовський відводив підручникам, яких, за його спостереженнями, також бракувало у гімназіях.

Вирішенню окреслених проблем мало слугувати, за Твардовським, Польське філософське товариство, відкриття якого відбулося за його ініціативи 12 лютого 1904 року. Метою товариства науковець визначив сприяння роботі у царині філософських наук, поширення філософських знань, піднесення рівня філософської освіти, визначаючи останню так само, як історичну, природничу та літературну освіту «складовою частиною загальної освіти» (Twardowski, 1904: s. 241). У 1934 році філософ створив у Товаристві секцію навчання філософії, яка займалась питаннями організації і методики викладання філософської пропедевтики.

Пропагуванню значимості філософської освіти у житті людини слугувала лекція Твардовського з циклу Загальних університетських лекцій Що таке філософія та навіщо ми ї̈ вивчаємо? (1904). Відповідаючи на другу частину запитання теми лекції, вчений пояснював, що у філософіï йдеться не «про спекуляції, а про людей взагалі» (Twardowski, 2013a: s. 488), тому користь від занять філософією полягає в одухотворенні життя людини, а також у привчанні іiі розуму до концентрації уваги лише силою волі. 3 огляду на це серед окремих філософських наук зна- 
чне місце науковець відводив логіці, користь від якої він порівнював із користю граматики. Вчений, подібно як загальну граматичну освіту, так і загальну логічну освіту, розглядав певним quantum знань та досвідом конкретних умінь, тому він ствержував про відсутність у людини загальної логічної освіти, якщо вона «не знає основних логічних понять чи не вміє коректно мислити» (Twardowski, 1919/20b: s. 185), так само, як говорять про відсутність у людини загальної граматичної освіти, якщо вона не знає, що таке прикметник чи не вміє коректно висловлюватися.

Слід відмітити, що вболівання Твардовського за філософську освіту випливало із його переконаності, подібно до Аристотеля, у вродженому потягу людини до знань. Значення знань у житті людини та суспільства філософ розглядав крізь метафору прометеєвого вогню. Найбільшого значення він надавав саме філософським знанням, тому що вони звільнюють людину від упереджень, помилок та оман, яких вона легко допускається, дивлячись на зовнішню сторону речі й досліджуючи лише iii поверхню. Філософські знання навчають людину завжди наближуватись до суті вчинків та дивитись на них відповідно до їх справжнього значення. Вони здатні вилікувати людину від нерозумної самовпевненості, завдяки якій їй видається, що вона - справжня вісь, довколо якої обертається життя. Крок на довгому та важкому шляху до філософських знань, який є відкритий кожній людині, філософ вважав кроком до тієї ідеальної мети життя, в якій збігаються усякі прагнення до знань, до сили та до щастя.

Твардовський розрізняв два етапи навчання філософії:

- пропедевтику філософії у середній школі;

- вивчення філософії в університеті.

Завданням середньої школи філософ визначав підготовку учня до навчання в університеті, у тому числі до вивчення філософії. 3 огляду на це дана підготовка повинна, на його думку, складатися з двох елементів: загальної освіти та філософської пропедевтики. У зв’язку з цим він порушив питання про зрівноваженість у середній школі об’ємів навчального матеріалу гуманітарних та природничо-математичних дисциплін, тому що нефілософські, спеціальні, науки:

- дають філософських наукам матеріал для досліджень;

- відіграють роль допоміжних по віношенню до певних філософських наук;

- забезпечують філософські науки методами дослідження.

3 погляду Твардовського, вивчення філософії та самостійна філософська праця повинні грунтуватись на досить загальній науковій підготовці у сфері нефілософського знання, оскільки у протилежному випадку 
таке вивчення філософії та така праця стають однобокими, що «тягне за собою дуже далекосяжну спеціалізацію, яка не узгоджується із самою суттю філософіï» (Twardowski, 1919/20a: s. 196). Істотного значення у вивченні філософії науковець надавав також історії філософії, тому що «як не можна займатись серйозно історією філософії, нехтуючи безпосередньо самими філософськими проблемами, так і навпаки - обізнаність з історією філософії буває, як правило, просто необхідним допоміжним засобом у формулюванні та розв’язуванні проблем» (Ibid.). Для Твардовського була очевидною у вивченні історії філософії та такою, що не потребувала свого доведення, вимога знання класичних мов. Звісно, вчений усвідомлював, що така наукова підготовка до філософії є радше ідеалом, аніж реальністю, втім, вважав, що «філософія дає людині стільки, що має право вимагати від неї теж багато - навіть забагато!» (Twardowski, 1919/20a: s. 197).

Аргумент необхідності грунтовного знання класичних мов у студіюванні філоофії науковець все ж навів у статті Грека, латина та філософiя (1933). Він доводив, що хто прагне студіювати філософію у значенні метафізики, тобто перш за все прагне до того, щоб «докладно пізнати відмінні погляди на світ, критично їх оцінити чи зробити один із них своїм власним поглядом, чи також самостійно створити на їх підставі власний погляд» (Twardowski, 1992: s. 447), той повинен знати мови, на яких протягом багатьох століть писали свої твори європейські філософи. Відстоювання такої думки Твардовського зумовлено тим, що філософські твори не є написані так однозначно як математичні твори, тому їхні переклади є лише «препарованими» крізь інтерпретації перекладачів текстами, позбавленими «чистого» тексту оригіналу. Необхідним у студіюванні філософії науковець також вважав знання сучасних іноземних мов - англійської, німецької, французької, італійської, проте розуміючи ідеальність такої підготовки у вивченні філософії, наголошував на потребі перекладів філософських праць, вказуючи на їхню необхідність не лише для професійних філософів.

Важливість філософської пропедевтики у середній школі вчений обгрунтовував тим, що вона:

- сприяє розумовому розвитку молоді, зосереджуючи іiі увагу «до власного духу і до того, що цей дух робить і що творить» (Twardowski, 1927a: s. 178);

- «ставить перед молоддю важливі з теоретичної та практичної точки зору проблеми та вчить їі до цих проблем належним чином підходиТи» (Ibid.);

- допомагає молоді узагальнити весь вивчений матеріал «з точки зору логічних критеріїв та категорій у світлі людської психіки» (Ibid.); 
- «озброює молодь критичним способом мислення, «тим самим оберігаючи ії як від вузького догматизму, так і від деструктивного песимізму» (Ibid.);

- навчає молодь точності у мисленні;

- знайомить молодь з низкою необхідних освіченій людині понять.

3 огляду на те, що мета філософської пропедевтики полягає, за Твардовським, у виробленні логічної сумлінності та чутливості, а також сприянні самостійному обдумуванню власного психічного життя, іiі важливу роль він розглядав не лише з дидактичного, але й з виховного, а через це - і з суспільного погляду. У зв’язку з цим філософ наголошував на безпідставності нарікання на безплідність вивчення філософської пропедевтики в середній школі, яка, на його думку, значною мірою виникала внаслідок нерозуміння їі важливості, через:

- брак достатньої кількості кваліфікованих вчителів пропедевтики філософії;

- відсутність відповідних підручників;

- занадто малу кількість годин, призначених для вивчення пропедевтики філософії;

- легковажне ставлення до філософії представників нефілософських наук через «звуженість та закостенілість їхнього розумового кругозоpy» (Twardowski, 1927a: s. 182).

Не менш виразно Твардовський заявляв також про належну філософську освіту для студентів. Викриваючи формальність підходу в університетах до філософської освіти як до складової частини загальної освіти, умови якісної наукової праці, а також уміння наукового мислення, він стверджував, що у дійсності випускники університетів виносять з нього «зазвичай лише більш-менш притомну згадку про те, що були на якихось лекціях з філософії і що навіть готувались до якогось іспиту з філософії, проте зазвичай не пам'ятають вже ані змісту тих лекцій, ані вивчених матеріалів до іспиту» (Twardowski, 1935: s. 3). Винятком із правила для Твардовського були один-два студенти. Особливо філософ наголошував на важливості філософської освіти у науковій праці. На його переконання, там, де відсутня філософська основа у науковій праці, відсутнє усвідомлення іiї єдності із філософськими проблемами та вміння висновувати з них належні у дослідженні результати, там наукова праця зазнає однобічного звуження у дослідженні, страждаючи на обмеженість загального рівня та глибини розуміння проблем. Тому у докладному вивченні філософських наук в університеті філософ вбачав передумову розвитку розумової культури народу, особливо тих іiї сфер, які конче потребують наукових досліджень. 
Метою студіювання філософії в університеті Твардовський визначав докладне ознайомлення з усіма філософськими науками, водночас грунтовне - з однією із них. Цю мету вчений пов'язав з вимогою паралельного студіювання одного нефілософського напряму, зв'язаного з обраною для грунтовного пізнання філософської науки. Філософська освіта потребує також грунтовного пізнання природничих наук та історії філософії. Зазначимо, що Твардовський не розділяв своїх студентів на філософів спеціалістів та неспеціалістів. Неспеціалісти вивчали той самий курс філософії, що й спеціалісти, за винятком окремих його частин. Курс філософії охоплював цикли лекцій з логіки, психології, історії філософії, етики, теорії пізнання.

Методику вивчення філософії в університеті Твардовський окреслив у статті Як студіювати філософію?(1910). Розуміючи під справжнім студіюванням філософії не лише «пізнання сенсу і походження найчастіш уживаних філософських виразів» (Twardowski, 1927b: s. 172) або «елементарні відомості про розвиток філософії (Ibid.), а власне «набуття здатності самостійного обдумування філософських проблем» (Ibid.), вчений насамперед заперечував необхідність розпочинати вивчення філософії з вивчення історії філософії. У слушності цього науковця переконувало студіювання нефілософських дисциплін: «Хіба той, хто прагне вчитися математики чи біології, починає свою працю з ознайомлення з розвитком математичних і біологічних наук, чи звертається спочатку до «компедіумів» та підручників, які подають більш чи менш вичерпно весь обсяг науки?» (Ibid.). Розуміння специфічності зв'язку між історією філософії та філософією на відміну від історії математики та математики чи історії біології та біології все ж не давало підстави філософу для ствердження думки про те, що «вивчення філософії слід розпочинати від студіювання історії філософіï» (Twardowski, 1927b: s. 173), а лише про висновуванння того, що «вивчення філософії слід поєднувати з вивченням історії філософії» (Ibid.). Адже можна бути досконалим біологом, не знаючи історії біології.

Для Твардовського очевидною була марність сподівань вивчити філософію за апріорного підходу. Студіювання філософії виключно чи переважно шляхом читання компедіумів, підручників чи нарисів науковець називав поверховим орієнтуванням у царині філософських наук. Як адепт анатомії не вивчає одразу ціле тіло, а розпочинає від препарування певного м'яза, так і адепт філософії, який по-справжньому хоче студіювати логіку чи психологію, етику чи естетику, чи теорію пізнання, повинен «обрати собі якусь проблему та пізнати ії якнайдокладніше на основі монографічних ії опрацювань. До цієї проблеми треба приглянутись з усіх уже висвітлених сторін i, доклавши зусиль, знайти в ній 
сторони ще досі ніким не висвітлені. [...] Пізнавши таким чином одну, другу, третю проблему, адепт філософії набуде вправності в розборі такого роду проблем загалом і зможе перейти до більш загального вивчення iii систематичних уявлень, оскільки лише тепер можна буде з них справді чогось навчитись» (Twardowski, 1927b: s. 173-174). Подібний принцип філософ пропонував і у вивченні історії філософії, оскільки вважав, що підручники з історії філософії «є вигідним способом набуття лише певного енциклопедичного ознайомлення з філософськими творами» (Twardowski, 1927b: s. 173), проте вони не можуть слугувати досконалими коментарями під час історіософських студій. «Адже ніхто не спирається при вивченні історії мистецтва на самий лише підручник» (Ibid.).

За такого підходу до студіювання філософії Твардовський наголошував на методологічному забезпеченні вивчення філософських проблем. У цьому сенсі важливого значення він надавав послідовності вивчення окремих філософських наук. «Ніхто не починає вивчення математики від диференційованих рівнянь, ані студіювання хімії від ії органічної частини. Тут і там є базові ділянки» (Twardowski, 1927b: s. 174). У вивченні філософії базовими дисциплінами вчений визначав логіку та психологію. «Логіка та психологія представляють два типи методів дослідження, котрі застосовуються також в царині філософських наук. Логіка поступає апріорно, психологія - емпірично» (Ibid.). Саме тому обізнаність з методами дослідження логіки, які вказують на умови визначення понять, та методи дослідження психології, які надають вичерпні відомості про закони, що керують психічним життям, становить методологічне підгрунтя студіювання філософії.

Для студентів філософів Твардовський висував додаткову вимогу: «вони мусять бути не тільки представниками філософії, але також іiі апостолами» (Twardowski, 1927e: s. 162-163).

Цікавими видаються думки вченого щодо сприяння розвитку національної філософії. Серцевиною національної філософії вчений вважав ствердження толерантності як здатності пізнати інші, «чужинні» філософії й прагнення розвивати власну філософію не через відмежування iї китайським муром від «чужинних» філософій, а доброякісне перетворення «чужої» на «власну» думку, плідний діалог з іншими філософіями й витворення на їхній підставі власної.

Підсумовуючи виклад, можна дійти висновків, що Твардовський актуалізував розуміння філософської освіти як складової частини загальної освіти людини. Підгрунтя філософської освіти - нефілософські знання та знання іноземних мов (класичних і сучасних). Раціональність - провідна ідея у вивченні філософії. Виявами раціональності, за Твардовським, є системність і послідовність викладу філософських дисци- 
плін; апостеріорність і конструктивність пізнання; ясність і точність мислення. Студіювання філософії - це спосіб життя та школа мислення. 3 огляду на це, гуманним актом сприяння самостійному творенню людиною власного погляду на світ та життя є не навчання філософії, причому певного типу, а навчання філософуванню. Розуміння філософії як полілогу різноманітних способів філософського мислення посилює гуманістичні інтенції філософа. Попри не налаштоване на сприйняття значимості філософської освіти суспільство, Твардовський переконував у иї життєвій потребі.

Передумовою розвитку філософії як королеви наук та провідної зірки життя Твардовський вважав плекання в людини потреби у ній. Суть концепції філософської освіти вченого полягає у навчанні описової та логіко-методологічної ясності і точності мислення. Дидактика філософіï Твардовського спонукає до розмислів над станом філософської освіти у середній та вищій школі в Україні, особливо в контексті подолання дидактичного формалізму «надати» філософські знання та «сформувати» світогляд тих, хто навчається. Розуміння значимості філософської освіти у привчанні людини до самостійного критичного мислення актуалізує філософію Твардовського також в контексті зростаючої складності сучасних взаємин людини і суспільства.

\section{Література:}

1. Twardowski K. (2013a) Co to jest filozofia i po co sie jej uczymy? // Kazimierz Twardowski. Mýsl, mowa i czyn. - Kraków: Copernicus Center Press, 2013. - s. 484488.

2. Twardowski K. (1927a) Filozofia w szkole średniej // Kazimierz Twardowski. Rozprawy i artykuły filozoficzne. - Lwów: Książnica-Atlas T.N.S.W, 1927. - s. 177-184.

3. Twardowski K. (1992) Greka i łatina a filozofia // Kazimierz Twardowski. Wybór pism psychologicznych i pedagogicznych. - Warszawa: Wydawnictwa Szkolne i Pedagogiczne, 1992. - s. 446-449.

4. Twardowski K. (1938) Historyczne pojęcie filozofii // Kazimierz Twardowski. Rozprawy. - Lwów: PTF im. K. Twardowskiego, 1938. - s. 7-9.

5. Twardowski K. (1927b) Jak studyować filozofie? // Kazimierz Twardowski. Rozprawy i artykuły filozoficzne. - Lwów: Książnica-Atlas T.N.S.W, 1927. - s. 172-176.

6. Twardowski K. (1927c) Nauka propedeutyki filozoficznej w gimnazyach // Kazimierz Twardowski. Rozprawy i artykuły filozoficzne. - Lwyw: Książnica-Atlas T.N.S.W, 1927. - s. 167-171.

7. Twardowski K. (1927d) O jasnym i niejasnym stylu filozoficznym // Kazimierz Twardowski. Rozprawy i artykuły filozoficzne. - Lwyw: Książnica-Atlas T.N.S.W, 1927. - s. 203-205.

8. Twardowski K. (1927e) O potrzebach filozofii polskiej // Kazimierz Twardowski. Rozprawy i artykuły filozoficzne. - Lwów: Książnica-Atlas T.N.S.W, 1927. - s. 129166. 
9. Twardowski K. (1919/20a) O przygotowaniu naukowem do filozofii // Ruch Filozoficzny. - 1919/20. - V. - n. 6. - s. 97-99.

10. Twardowski K. (1904) Otwarcie Polskiego Towarzystwa Filozoficznego we Lwowie // Przegląd Filozoficzny. - 1904. - R.VII. - s. 239-243.

11. Twardowski K. (1919/20b) O wykształcenie logiczne // Ruch Filozoficzny. - 1919/20. - V. - n. 4.5. - s. 65-71.

12. Twardowski K. (1929) Przemówienie, wygloszone na odchodzie dwudziestopięciolecia Polskiego Towarzystwa Filozoficznego we Lwowie dnia 12. lutego 1929, Lwów, 1929. $15 \mathrm{~s}$.

13. Twardowski K. (1927f) Psychologia wobec fizjologii i filozofii // Kazimierz Twardowski. Rozprawy i artykuły filozoficzne. - Lwyw: Książnica-Atlas T.N.S.W, 1927. - s. 3-32.

14. Twardowski K. (1935) Więcej filozofii! // Ruch Filozoficzny. - 1935. - R. 13. - n. 1-4. - s. $1-5$.

15. Twardowski K. (2013b) Wykład wstepny w Uniwersytecie Lwowskim // Kazimierz Twardowski. Mýsl, mowa i czyn. - Krakyw: Copernicus Center Press, 2013. - s. 457 467.

\section{Ольга Гончаренко. Философия и философское образование в понимании Казимира Твардовского}

Самоопределение философии, ее место и значение в жизни человека и общества - давняя философская проблема. Попытку ее решения выдающимся польским философом, Казимиром Твардовским, предложено проанализировать читателю в статье. Свободная от крайностей метафизицизма и минимализма философия Твардовского не только создала условия для расцвета философской культуры, но и воспитала плеяду философски вышколенных ученых. Анализ особенностей понимания философии талантливым ученым и педагогом, а также предпосылки ее развития - философского образования - побуждают к размышлениям над проблемами в отечественной философии. Философско-педагогическое осмысление опыта Твардовского является актуальным и в контексте возрастающей сложности современных взаимоотношений человека и общества.

Ключевые слова: польская философия, Казимир Твардовский, философия, философское образование.

\section{Olha Honcharenko. Philosophy and Philosophical Education in Kazimierz Twardowski's Interpretation}

Philosophy determination, its place and purpose in human life and society is the eternal philosophical problem. In this paper the reader is suggested to analyze the attempt of its solving by outstanding Polish philosopher Kazimierz Twardowski. Free from the extremes of metaphysics and minimalism, Kazimierz Twardowski's philosophy has not only created the conditions for philosophical culture development, but has also brought up a pleiad of philosophically educated scientists. What are the peculiarities of Kazimierz Twardowski's philosophy? On the bases of philosophical papers analysis, scientific and historical definition of the 
concept of philosophy has been carried out. It is proved, that the scientific concept of philosophy, as one of the components of polylogue manifestation of the human spirit, dissolves in historical concept of philosophy. Such philosophy understanding brought the philosopher to the conclusion about vital human and social necessity in philosophy. If a man and society do not feel the necessity in philosophy, due to the lack of their spiritual culture, this necessity should be grown. Therefore, the care about philosophical education was one of the main goals of Twardowski's life. The scientist interpreted philosophical education as a part of general education. He determined philosophy studies as a way of life and a school of thinking. Due to this, Twardowski believed that method studying as natural means of knowledge and self-cognition is a humane act promoting creating man's own view of the world. Special understanding of the philosophy and the background of its development philosophical education by talented scientist and teacher - encourages reflection on the problems in the field of Ukrainian philosophy. Philosophical and pedagogical understanding of Twardowski's experience is relevant in the context of increasing complexity of modern relationships between a man and society.

Keywords: Polish philosophy, Kazimierz Twardowski, philosophy, philosophical education.

Гончаренко Ольга Анатоліївна - кандидат філософських наук, доцент, доцент кафедри педагогіки та соціально-економічних дисциплін Національної академії Державної прикордонної служби України імені Богдана Хмельницького.

E-mail: olgegoncharenko@gmail.com

Honcharenko Olha Anatoliivna - PhD, Associate Professor, Associate Professor of the Social and Economic Disciplines Department of the National Academy of State Border Service of Ukraine named after Bohdan Khmelnytskyi. 